\title{
Phytophthora infestans Populations from Tomato and Potato in North Carolina Differ in Genetic Diversity and Structure
}

\author{
T. Wangsomboondee, C. Trout Groves, P. B. Shoemaker, M. A. Cubeta, and J. B. Ristaino
}

Department of Plant Pathology, North Carolina State University, Raleigh 27695.

Current address of C. T. Groves: U.S. Department of Agriculture, Agricultural Research Service, New England Plant, Soil and Water

Laboratory, Orono, Maine.

Accepted for publication 3 July 2002.

\begin{abstract}
Wangsomboondee, T., Groves, C. T., Shoemaker, P. B., Cubeta, M. A., and Ristaino, J. B. 2002. Phytophthora infestans populations from tomato and potato in North Carolina differ in genetic diversity and structure. Phytopathology 92:1189-1195.

Phytophthora infestans causes a destructive disease on tomato and potato. In North Carolina (NC) potatoes are mostly grown in the east, whereas tomatoes are grown in the mountainous areas in the western part of the state. Five genotypes of $P$. infestans were identified from 93 and 157 isolates collected from tomato and potato over a 5 year period between 1993 and 1998. All isolates collected from potato in eastern NC were the US- 8 genotype, whereas only a single isolate was the US-1 genotype. Tuber blight was found on immature daughter tubers in a single field in 1997, however infection on mature tubers was not observed.
\end{abstract}

ABSTRACT

Late blight, caused by the oomycete pathogen Phytophthora infestans (Mont.) de Bary, has re-emerged as a serious disease of tomato and potato in the United States and Canada during the last decade (12). Disease increases have been attributed to increased resistance to the fungicide metalaxyl and associated with genetic changes in populations of $P$. infestans $(3,5,19,20,22,29)$. The migration of $P$. infestans via infected potato and tomato plants from Mexico and sexual reproduction of the pathogen have contributed to genetic changes in recent populations of the pathogen $(8,13$, 19,21). Comparison of mating type, allozyme genotype at the glucose-6-phosphate isomerase (Gpi) and peptidase (Pep) loci, and DNA fingerprinting with the RG57 probe have confirmed that populations composed of new genotypes are rapidly replacing the former genotypes $(13,14)$. Data also indicate that new genotypes of $P$. infestans may exhibit greater fitness than old genotypes (27).

Studies of populations of $P$. infestans in the tomato and potato growing regions in North Carolina (NC) began in the early 1990s $(11,19)$. Large-scale production of potato is geographically isolated in the eastern part of the state, whereas large-scale tomato production occurs in the western part of the state. Epidemics of the disease have occurred yearly in tomato growing areas of $\mathrm{NC}$ between 1991 and 1998. Tomatoes can only be produced in western NC if multiple fungicide applications are made for early and late blight control. In contrast, the disease was uncommon prior to 1993 in potato growing areas of $\mathrm{NC}$, but since then, epidemics have occurred sporadically in different fields, and in those fields, severe disease has occurred (11).

In a previous study, isolates of $P$. infestans collected in NC between 1993 and 1995, primarily from tomato, were characterized

Corresponding author: J. B. Ristaino; E-mail address: Jean_Ristaino@ncsu.edu

Publication no. P-2002-0909-01R

(C) 2002 The American Phytopathological Society
Within potato fields, a range of sensitivity to metalaxyl was observed among isolates but all were either intermediate or highly resistant to the fungicide. In contrast, isolates from tomatoes included previously reported US-7 and US-8 genotypes and two new genotypes called US-18 and US-19 (A2 mating type, allozyme genotype Gpi 100/100 and Pep 92/100). These genotypes had unique restriction fragment length polymorphism banding patterns, were sensitive to metalaxyl, and have not been reported elsewhere. All genotypes, with the exception of the US-1, were the Ia mitochondrial haplotype. Thus, isolates of $P$. infestans from tomato were more genetically diverse over time in NC than those from potato and include two new genotypes that are sensitive to metalaxyl.

Additional keywords: epidemiology, Irish potato famine, population genetics.

using allozymes at Gpi and Pep loci, mating type, and metalaxyl sensitivity (11). Four different allozyme genotypes (US-1, US-7, US-8, and US-18) were identified in NC (11). The US-18 genotype was first isolated in eastern Tennessee in 1994. DNA fingerprinting of the isolates was not conducted in the previous study (11). The dynamics of changes in genotypes of $P$. infestans have been examined in many areas of the United States $(12,13,19,21,22)$, but only a single study has been conducted in NC (11).

The occurrence of metalaxyl resistant isolates in populations of $P$. infestans has played a major role in the increased severity of late blight epidemics observed in recent years $(3,5,22)$. It is believed that resistance in the United States and Canada originated from migration of resistant isolates rather than by mutation and selection after migration (22). In contrast, resistance to metalaxyl in Europe may have evolved from selection of metalaxyl resistant mutants within clonal lineages (22). Likewise, in Africa, metalaxyl resistant isolates have been found within the US-1 clonal lineage (35). A dominant locus responsible for resistance has been shown to have different chromosomal locations in different isolates (10). It is likely that development of metalaxyl resistance in $P$. infestans may have arisen independently in different areas of the world. Variation in the level of sensitivity to metalaxyl within the US-7 and US-8 genotypes of $P$. infestans has also been observed (11). In NC, US-7 and US-8 genotypes consisted of both intermediate and highly resistant isolates and there was not a complete correlation between genotype and metalaxyl sensitivity (11).

The present study was conducted to more thoroughly examine the genetic structure and diversity among isolates of $P$. infestans sampled from tomato and potato in NC between 1993 and 1998. Because the two host crops are geographically isolated in $\mathrm{NC}$, we were interested in determining whether the same inoculum sources were responsible for epidemics. We used additional geno- 
typic markers including mitochondrial DNA (mtDNA) haplotyping and DNA fingerprinting with the probe RG57 to further examine the genetic structure of populations from potato and tomato. We expanded our sample of isolates on potato and evaluated within-field variation in sensitivity to metalaxyl. A preliminary report of a portion of this work has been presented (36).

\section{MATERIALS AND METHODS}

Fungal isolates and cultures. Late blight-infected tomato and potato samples were collected from various locations in NC between 1993 and 1998 (Table 1). Two hundred fifty isolates of $P$. infestans from 54 fields in NC were examined over the course of this study (Table 1). Samples were taken to maximize the number of different field locations sampled. Multiple samples from infected potato were collected from multiple foci within a field early in epidemic development in Washington County in 1997, and in 1998 from two different fields in Sampson and Greene counties (Table 1). Samples from four potato fields in Pasquotank County in 1998 were also collected. Leaves were sampled in most fields, but isolates from the field in Washington County in 1997 were obtained from tubers, leaves, and stems.

Pure cultures were obtained by placing infected plant tissue in plastic bags or petri dishes lined with moistened filter paper and incubating at $18^{\circ} \mathrm{C}$ for 1 to 2 days until sporulation occurred. A small piece of rye $\mathrm{B}$ agar on the tip of a hypodermic needle was touched to sporangia and transferred to rye B agar (22). For tissue without obvious sporulation, the pathogen was isolated after

TABLE 1. Isolates of Phytophthora infestans collected from potato and tomato fields in North Carolina between 1994 and 1998 and tested for mating type, genotype, and mitochondrial DNA (mtDNA) haplotype

\begin{tabular}{|c|c|c|c|c|c|}
\hline Year & Location, County & $\begin{array}{l}\text { No. of } \\
\text { isolates }\end{array}$ & $\begin{array}{l}\text { Mating } \\
\text { type }\end{array}$ & $\begin{array}{l}\text { Geno- } \\
\text { type }^{a}\end{array}$ & $\mathrm{mtDNA}^{\mathrm{b}}$ \\
\hline \multicolumn{6}{|c|}{ Potato isolates } \\
\hline 1994 & Camden & 1 & $\mathrm{~A} 1$ & US-1 & $\mathrm{Ib}$ \\
\hline 1994 & Fletcher & 1 & A2 & US-7 & Ia \\
\hline 1994 & Washington & 5 & A2 & US- 8 & Ia \\
\hline 1994 & Yancey & 1 & A2 & US-8 & Ia \\
\hline 1994 & Fletcher & 1 & A2 & US-7 & Ia \\
\hline 1995 & Washington & 2 & A2 & US-8 & Ia \\
\hline 1996 & Pasquotank & 6 & $\mathrm{~A} 2$ & US-8 & Ia \\
\hline 1997 & Washington & 39 & A2 & US-8 & Ia \\
\hline 1998 & Greene & 46 & A2 & US-8 & Ia \\
\hline 1998 & Sampson & 35 & A2 & US- 8 & Ia \\
\hline 1998 & Pasquotank, field 1 & 5 & A2 & US-8 & Ia \\
\hline 1998 & Pasquotank, field 2 & 5 & $\mathrm{~A} 2$ & US-8 & Ia \\
\hline 1998 & Pasquotank, field 3 & 5 & A2 & US-8 & Ia \\
\hline 1998 & Pasquotank, field 4 & 5 & A2 & US-8 & Ia \\
\hline \multicolumn{6}{|c|}{ Tomato isolates } \\
\hline 1993 & Fletcher & 1 & A2 & US-7 & Ia \\
\hline 1993 & Yancey & 1 & A2 & US-7 & Ia \\
\hline 1993 & Alleghany, field 1 & 1 & A2 & US-8 & Ia \\
\hline 1993 & Alleghany, field 2 & 1 & A2 & US-7 & Ia \\
\hline 1994 & Charleston $^{c}$ & 1 & A2 & US-7 & Ia \\
\hline 1994 & Macon, field 1 & 6 & $\mathrm{~A} 2$ & US-7 & Ia \\
\hline 1994 & Macon, field 2 & 1 & A2 & US-8 & Ia \\
\hline 1994 & Yancey & 1 & A2 & US-8 & Ia \\
\hline 1994 & Madison & 1 & A2 & US-8 & Ia \\
\hline 1994 & Henderson & 2 & A2 & US-7 & Ia \\
\hline 1994 & Fletcher & 1 & A2 & US-7 & Ia \\
\hline 1994 & Haywood & 1 & A2 & US-7 & Ia \\
\hline 1995 & Waynesville & 3 & A2 & US-18 & Ia \\
\hline 1996 & Fletcher & 8 & A2 & US-18 & Ia \\
\hline 1996 & Waynesville & 3 & A2 & US-18 & Ia \\
\hline 1996 & Yadkin & 3 & A2 & US-18 & Ia \\
\hline 1997 & Fletcher & 5 & A2 & US-19 & Ia \\
\hline 1998 & Waynesville & 3 & A2 & US-18 & Ia \\
\hline
\end{tabular}

${ }^{a}$ Genotype was determined by DNA fingerprinting with the RG57 probe (19).

b mtDNA haplotype was determined by methods of Griffith and Shaw (23).

c Isolate from South Carolina. inoculating a potato tuber bait. Surface-disinfected tuber slices ( $5 \mathrm{~mm}$ thick) were placed on top of infected tissue in a petri dish. The petri dishes were put in a moist chamber and incubated at $18^{\circ} \mathrm{C}$ for 5 to 7 days. Once sporulation was observed, isolation was made as described previously. Pea broth (120 g of frozen peas per liter of sterile distilled water) was used to culture mycelia of $P$. infestans for allozyme analysis, mtDNA haplotyping, and restriction fragment length polymorphism analysis. Mycelia was removed from the broth by vacuum filtration on Whatman No. 1 filter paper and kept frozen at $-20^{\circ} \mathrm{C}$ for future use.

Mating type. Mating type was determined by placing an unknown isolate between $(2.5 \mathrm{~cm})$ known A1 (94-1, US-1 genotype) and A2 (93-4, US-8 genotype) tester isolates of $P$. infestans on rye $\mathrm{B}$ agar media. Hyphal interaction zones were observed microscopically after 7 to 10 days of incubation at $18^{\circ} \mathrm{C}$ in dark. Oospores were produced in the margins of opposite mating types. Isolates that produced oospores with the known A1 tester isolate were designated the A2 mating type and isolates that produced oospores with the known A2 tester isolate were designated the A1 mating type. Positive controls consisted of pairings between the opposite mating type of tester isolates, and negative controls consisted of pairing between isolates of the same mating type.

Allozyme analysis. Mycelia obtained from pea broth culture as described previously was cut into small pieces $\left(0.5\right.$ to $\left.1 \mathrm{~cm}^{2}\right)$ and placed in sterile $1.5-\mathrm{ml}$ microcentrifuge tubes. The mycelia was centrifuged at $8,000 \times g$ to remove excess water. Fifty microliters of extraction buffer (20\% sucrose, $2 \%$ Triton X-100, $0.01 \%$ bromophenol blue, and $9.8 \mathrm{ml} \mathrm{of} \mathrm{H}_{2} \mathrm{O}$ ) and $10 \mathrm{mg}$ of glass beads (Sigma Chemical, St. Louis) were added to each tube and the mycelia was ground for $30 \mathrm{~s}$ with a hand drill equipped with a separate, sterile Konte pestle for each isolate. Samples were centrifuged for $3 \mathrm{~min}$ at $8,000 \times g$, and the supernatant was collected for allozyme analysis.

Allozyme genotypes were determined on all isolates at the $G p i$ locus and for some isolates at the Pep locus by polyacrylamide gel electrophoresis using the Phastsystem (Amersham Biosciences, Piscataway, NJ) according to methods described previously (11, 18). Precast homogeneous polyacrylamide gels (12.5\%) and standard native buffer strips were used for the Gpi assay, while homogeneous polyacrylamide gels $(12.5 \%)$ with agarose buffer strips made with Tris-citrate buffer $(0.155 \mathrm{M}$ Tris and $0.043 \mathrm{M}$ citric acid, $\mathrm{pH}$ 7.0) were used for the Pep assay. The agarose buffer strips were prepared with $3 \%$ agarose using buffer strip molds (Amersham Biosciences) (11).

Isolates of the four clonal genotypes US-1, US-6, US-7, and US-8 were used as standards on each gel (18). Migration distances of proteins from the unknown isolates were compared with migration distances of proteins from the known genotypes. Alleles in individual isolates were scored based on the migration of their proteins relative to the protein produced at the 100 allele (18).

mtDNA haplotyping. DNA from a subset of isolates of $P$. infestans was extracted according to the cetyltrimethylammonium bromide (CTAB) extraction method (34). mtDNA haplotyping was performed via polymerase chain reaction (PCR) (23). Two primer sets were used that amplify the P2 and $\mathrm{P} 4(2 \mathrm{~F} / 2 \mathrm{R}$ and 4F/4R) regions of mtDNA of $P$. infestans (23). The final PCR reaction volume of $30 \mu \mathrm{l}$ consisted of $1 \mu \mathrm{l}$ ( 1 to $10 \mathrm{ng}$ ) of template DNA, $3 \mu \mathrm{l}$ of $10 \times$ buffer ( $100 \mathrm{mM}$ Tris- $\mathrm{HCl}, 15 \mathrm{mM} \mathrm{MgCl}_{2}$, and $500 \mathrm{mM} \mathrm{KCl}, \mathrm{pH} 8.3$ ), $14.01 \mu \mathrm{l}$ of sterile distilled $\mathrm{H}_{2} \mathrm{O}, 200 \mu \mathrm{M}$ each dNTPs, $2.75 \mathrm{mM} \mathrm{MgCl} 2,0.325 \mu \mathrm{M}$ forward and reverse primers of either $2 \mathrm{~F}\left(5^{\prime}\right.$-TTCCCTTTGTCCTCTACCGAT- $\left.3^{\prime}\right)$ and 2R (5'-GCTTATGCTTCAGTTGCTCAT- $\left.3^{\prime}\right)$ or 4F (5'-TGGTCATCCAGAGGTTT-ATGTT- $\left.3^{\prime}\right)$ and 4R (5'-CCGATACCGATACCAGCACCAA-3') (23), $160 \mu \mathrm{g}$ of bovine serum albumin per $\mathrm{ml}$, and 0.1 unit of Taq polymerase. All reactions were overlaid with sterile mineral oil prior to thermal cycling. Thermal cycling parameters were an initial denaturation at $94^{\circ} \mathrm{C}$ for $90 \mathrm{~s}$ followed by 40 cycles consisting of denaturation at $94^{\circ} \mathrm{C}$ for $40 \mathrm{~s}$, annealing at 
$55^{\circ} \mathrm{C}$ for $60 \mathrm{~s}$, and extension at $72^{\circ} \mathrm{C}$ for $90 \mathrm{~s}$. A final extension at $72^{\circ} \mathrm{C}$ for $10 \mathrm{~min}$ followed.

PCR products from the P2 (1,240 bp) and P4 (957 bp) regions of mtDNA were digested with $M s p \mathrm{I}$ and EcoRI, respectively, at $37^{\circ} \mathrm{C}$ for $2 \mathrm{~h}$. Digested products were subject to electrophoresis on $1.6 \%$ agarose gels containing $0.5 \mu \mathrm{g}$ of ethidium bromide per $\mathrm{ml}$ with $1 \times$ Tris-borate-EDTA running buffer. A 100-bp DNA ladder was included on each gel as a molecular size standard.

DNA fingerprinting. DNA was extracted from frozen mycelia according to a modification of Goodwin et al. (17). Two to four plates of mycelia from pea broth cultures of each isolate were vacuum-filtered through Whatman No. 1 filters and lyophilized at $-5^{\circ} \mathrm{C}$ for $12 \mathrm{~h}$. Lyophilized mycelia was ground in liquid nitrogen, suspended in $4 \mathrm{ml}$ of prewarmed $\left(65^{\circ} \mathrm{C}\right)$ extraction buffer $(50 \mathrm{mM}$ Tris, $\mathrm{pH} 8.0,150 \mathrm{mM}$ EDTA, and 1\% Sarkosyl), vortexed for $60 \mathrm{~s}$, and incubated for $20 \mathrm{~min}$ at $65^{\circ} \mathrm{C}$. Four milliliters of cold $5 \mathrm{M} \mathrm{NH}_{4} \mathrm{OAc}$ was added to each tube, which were then mixed by inversion, placed on ice for $20 \mathrm{~min}$, and centrifuged for $10 \mathrm{~min}$ at $8,240 \times g$. The supernatant was transferred to a new tube, precipitated with a two-thirds volume of isopropanol, and centrifuged for $5 \mathrm{~min}$ at $8,240 \times g$. The pellets were dried and resuspended in $0.5 \mathrm{ml}$ of Tris-EDTA (TE) buffer (10 mM Tris, $\mathrm{pH} 8.0$, and $1 \mathrm{mM}$ EDTA). The DNA suspension was transferred to a new $1.5-\mathrm{ml}$ microcentrifuge tube and RNase A (Boehringer Mannheim, IN) was added to a final concentration of $0.1 \mathrm{mg} / \mathrm{ml}$. The tubes were incubated for $20 \mathrm{~min}$ at $37^{\circ} \mathrm{C}$ and extracted twice with 1 volume of phenol/chloroform/isoamyl alcohol (25:24:1). DNA was precipitated with 0.1 volume of $3 \mathrm{M} \mathrm{NaOAc}$ and 2 volumes of absolute ethanol. The tubes were centrifuged for $15 \mathrm{~min}$ to pellet the DNA. Pellets were washed with $70 \%$ ethanol, air dried, and resuspended in 100 to $300 \mu \mathrm{l}$ of TE buffer. Two micrograms of DNA was digested with EcoRI and subjected to electrophoresis on $0.8 \%$ agarose gels at $50 \mathrm{~V}$ for $18 \mathrm{~h}$. Southern transfer was performed by depurination in $300 \mathrm{ml}$ of $0.25 \mathrm{M} \mathrm{HCl}$ for $10 \mathrm{~min}$, and denaturation in $1 \times$ Southern base solution $(10 \mathrm{~g}$ of $\mathrm{NaOH}$ and $87.63 \mathrm{~g}$ of $\mathrm{NaCl}$ per liter) twice for $15 \mathrm{~min}$ each. DNA was transferred to nylon membranes (Hybond-N+, Amersham Biosciences) by capillary transfer overnight. The membrane was neutralized in $200 \mathrm{ml}$ of $1 \mathrm{M}$ Tris, $\mathrm{pH} 7.5$, and $1.5 \mathrm{M} \mathrm{NaCl}$ for 2 to $3 \mathrm{~min}$. DNA was fixed on the membrane by UV cross-linking. Hybridization with the RG57 probe (17) was performed following the protocol of the random primer fluorescein labeling kit with antifluoresceinAP (NEN Life Science Products, Boston). The method of purification of the fluorescein-labeled probe was modified from the protocol by precipitating the labeled DNA probe in 2 volumes of absolute ethanol and 0.1 volume of $3 \mathrm{M} \mathrm{NaOAc}$ for $12 \mathrm{~h}$, washing with $70 \%$ alcohol, and resuspending in 50 to $100 \mu \mathrm{l}$ of TE buffer. Known US-1, US-6, US-7, and US-8 genotypes were used as standards.

Metalaxyl sensitivity of isolates. Metalaxyl sensitivity of isolates collected from 1996 to 1998 was examined on rye B agar amended with 0,5 , and $100 \mu \mathrm{g}$ of metalaxyl per ml (Ridomil 2E, Syngenta, Research Triangle Park, NC). A single disk $(0.5 \mathrm{~cm})$ of mycelia from each isolate was transferred to rye $\mathrm{B}$ agar amended with metalaxyl as described previously and incubated at $18^{\circ} \mathrm{C}$ for 10 to 14 days. Two replications were conducted per treatment for each isolate, and the experiment was repeated at least twice. Radial growth of each colony was measured after 10 to 14 days, and the relative growth rate of each isolate at each metalaxyl concentration was calculated as a percentage of the growth on

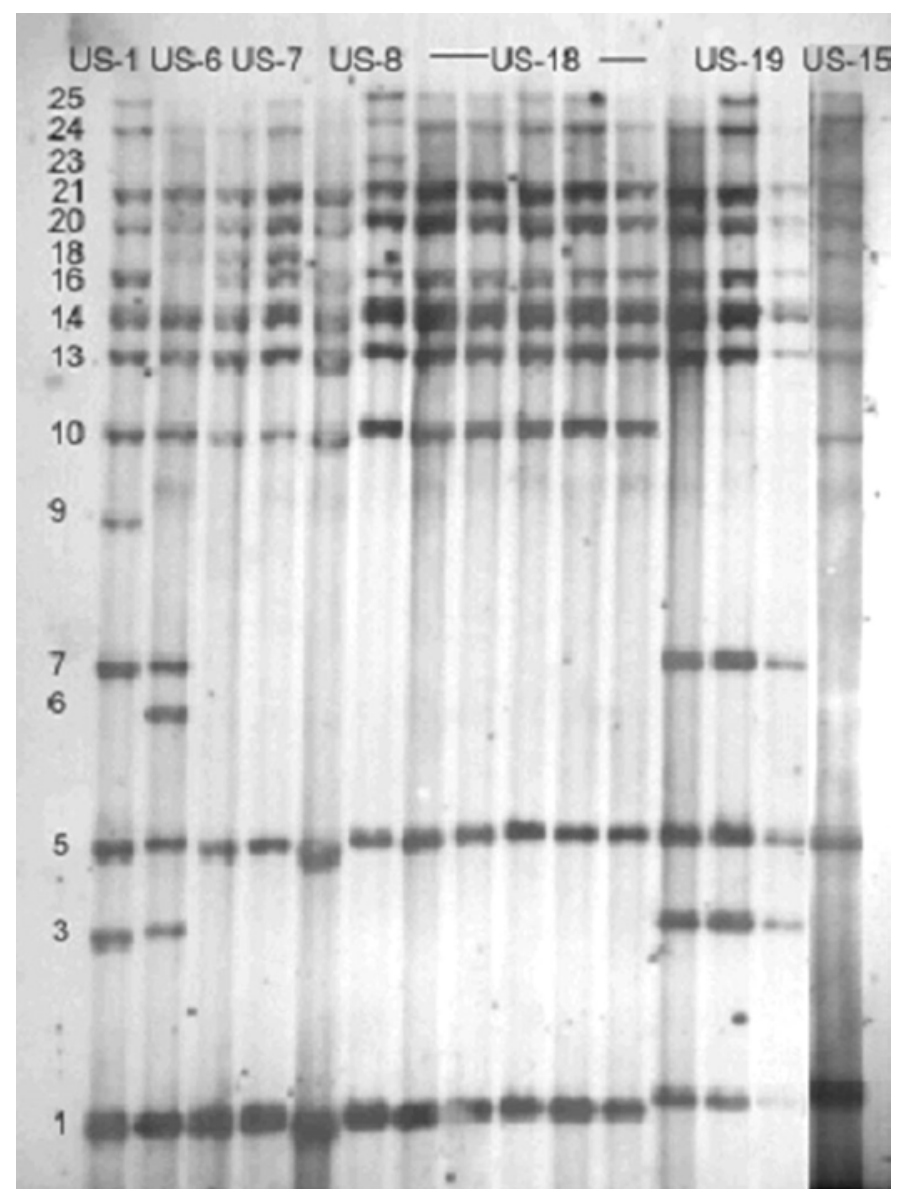

Fig. 1. DNA fingerprint patterns with RG57 probe of five genotypes (US-1, US-7, US-8, US-18, and US-19) of Phytophthora infestans found in North Carolina between 1993 and 1998 compared with US-6 and US-15 genotypes. Genotype names are indicated above each lane. RG57 fingerprint band numbers are indicated on the left. Isolates numbers from lanes 1 to 15 are 941 (US-1), 94-52 (US-6), 93-1 (US-7), 93-5 (US-7), 95-4-2 (US-8), 97-24 (US-8), 96-6-2 (US-18), 96-7-4 (US-18), 96-9-3 (US-18), 95-9-1 (US-18), 98-104 (US-18), 97-1-1 (US-19), 97-1-2 (US-19), 97-1-3 (US-19), and 80787-94L (US-15), respectively.

TABLE 2. Allozyme genotypes of isolates of Phytophthora infestans collected from potato and tomato fields in North Carolina between 1993 and 1998

\begin{tabular}{|c|c|c|c|c|c|c|c|c|c|}
\hline \multicolumn{2}{|c|}{ Allozyme genotype ${ }^{a}$} & \multirow[b]{2}{*}{ Genotype } & \multicolumn{7}{|c|}{ Number of isolates } \\
\hline Gpi & Pep & & 1993 & 1994 & 1995 & 1996 & 1997 & 1998 & Total \\
\hline \multicolumn{10}{|l|}{ Potato } \\
\hline $86 / 100$ & $92 / 100$ & US-1 & 0 & 1 & 0 & 0 & 0 & 0 & 1 \\
\hline $100 / 111$ & $100 / 100$ & US-7 & 0 & 2 & 0 & 0 & 0 & 0 & 2 \\
\hline \multirow[t]{2}{*}{$100 / 111 / 122$} & $100 / 100$ & US-8 & 0 & 6 & 3 & 6 & 39 & 100 & 154 \\
\hline & & & & & & & & & 157 \\
\hline \multicolumn{10}{|l|}{ Tomato } \\
\hline $100 / 111$ & $100 / 100$ & US-7 & 4 & 48 & 1 & 0 & 0 & 0 & 53 \\
\hline $100 / 111 / 122$ & $100 / 100$ & US-8 & 1 & 14 & 0 & 0 & 0 & 0 & 15 \\
\hline $100 / 100$ & $92 / 100$ & US-18 & 0 & 0 & 3 & 14 & 0 & 3 & 20 \\
\hline \multirow[t]{2}{*}{$100 / 100$} & $92 / 100$ & US-19 & 0 & 0 & 0 & 0 & 5 & 0 & 5 \\
\hline & & & & & & & & & 93 \\
\hline
\end{tabular}

${ }^{a}$ Genotype was identified by allozyme analysis at glucose-6-phosphate isomerase (Gpi) and peptidase (Pep) loci. 
nonamended rye $\mathrm{B}$ media (control plate). Isolates with a colony diameter less than $40 \%$ of the nonamended control at 5 and $100 \mu \mathrm{g} / \mathrm{ml}$ were classified as metalaxyl sensitive. Isolates with a colony diameter greater than $40 \%$ of the nonamended control at $5 \mu \mathrm{g} / \mathrm{ml}$ but less than $40 \%$ of the nonamended control at $100 \mu \mathrm{g} / \mathrm{ml}$ were classified as intermediate. Isolates with a colony diameter greater than $40 \%$ of the nonamended control at both 5 and $100 \mu \mathrm{g} / \mathrm{ml}$ were classified as metalaxyl resistant (6).

\section{RESULTS}

Mating type. All isolates from potato and tomato were the A2 mating type with the exception of a single A1 isolate collected from a potato field in Camden County in 1994 and reported previously (11) (Table 1). Oospores were produced on the control plates inoculated with tester isolates of the opposite mating types and were not produced on plates inoculated with tester isolates of the same mating type.

Allozyme genotypes. Four different allozyme genotypes were identified among isolates of $P$. infestans collected between 1993 and 1998 from tomato and potato. The US-8 genotype (A2, Gpi 100/111/122 and Pep 100/100) was the only genotype identified from potato in eastern NC after 1994 (Table 2). Fifty-three isolates collected from tomato prior to 1996 were the US-7 genotype (A2, Gpi 100/111 and Pep 100/100) (Table 2). No US-7 genotypes were found among isolates from tomato or potato after 1995 (Table 2). The remaining 25 isolates collected from tomato between 1995 and 1998 were Gpi 100/100 and Pep 92/100 (Table 2). The allozyme genotype resembled US-6 but isolates were A2 mating type and sensitive to metalaxyl unlike previously identified US-6 genotypes (19). Three of these isolates collected in 1995 were identified as novel and named the US-18 genotype by allozyme genotyping in previous work (11).

DNA fingerprinting. The DNA fingerprint patterns of the three genotypes identified in NC (US-1, US-7, and US-8) and two other genotypes, not observed in NC, US-6 and US-15, were compared with the DNA fingerprints of the US-18 genotype found in western NC on tomatoes (Fig. 1; Table 3). Although US-18 had an allozyme genotype that was identical to US-6 at both the Gpi and Pep loci (Table 3), the DNA fingerprint patterns of this group indicated two distinct genotypes (Fig. 1). The DNA fingerprint of the US-18 genotype was most similar to the US-8 genotype with the exception that band 23 was not present in any isolates of the US-18 genotype tested. A novel genotype named US-19, collected in 1997 in Fletcher, was also A2, Gpi 100/100 and Pep 92/100, however the DNA fingerprint pattern was clearly different from US-18 (Fig. 1). The DNA fingerprint pattern of the US-19 genotype was similar to the US-1 and US-6 genotypes with the exception that bands 9 and 10 from US- 1 and bands 6, 10, and 18 from
US-6 were not present (Fig. 1; Table 3). The DNA fingerprint patterns of US-18 and US-19 were different from each other and from US-15 (Fig. 1). The isolate of the US-15 genotype obtained from S. Kim in Pennsylvania (personal communication) is also A2, Gpi 100/100 and Pep 92/100, but has a unique DNA fingerprint that was not reported previously (19) and is shown here (Fig. 1; Table 3). Cultures of the US-15, US-18, and US-19 genotypes have been deposited into the Phytophthora collection at the University of California, Riverside, and the American Type Culture Collection, Rockville, MD.

mtDNA haplotyping. Four mtDNA haplotypes (Ia, Ib, IIa, and IIb) have been reported in P. infestans (23) (Fig. 2). Little variation was observed in mtDNA haplotypes among isolates in NC. All isolates of the US-7, US-8, US-18, and US-19 genotypes were the Ia mtDNA haplotype (Table 1). The US-1 genotype was the Ib mtDNA haplotype (Fig. 2). The IIa and IIb mtDNA haplotypes were not found among isolates of $P$. infestans on either potato or tomato in NC.

Metalaxyl sensitivity. Twenty-six (12.2\%) isolates of P. infestans collected from tomato and potato between 1993 and 1998 were sensitive, 57 isolates $(26.8 \%)$ were intermediate, and 130 isolates $(61 \%)$ were resistant to metalaxyl (Table 4). Variation for metalaxyl sensitivity was observed within genotypes of these isolates. Isolates that were sensitive to metalaxyl were identified among isolates of the US-7, US-18, and US-19 genotypes from tomato (Table 4), but no metalaxyl sensitive isolates were identified among isolates of the US-8 genotype from either host (Table 4). Isolates with intermediate sensitivity to metalaxyl were found among US-7, US-8, US-18, and US-19 genotypes from both tomato and potato.

Isolates of the US-8 genotype were collected from potato in eastern NC in 1997 and 1998 (Table 1). The pathogen was isolated from tubers, leaves, and stems of potato from a field in Washington County in 1997. To our knowledge, this was the first report of tuber blight from immature daughter tubers in NC. Little blight was observed on mature tubers in the field. In 1998, late blight on potato occurred for the first time in two fields in Greene and Sampson counties (Table 1). Variation in metalaxyl sensitivity was observed among isolates of the US-8 genotype obtained from these three fields (Fig. 3A). Seventy-five percent of isolates obtained in the Greene County field were intermediate in sensitivity to metalaxyl, whereas 22 and $48 \%$ were intermediate in sensitivity to metalaxyl in the fields in Washington and Sampson counties. Equal percentages of isolates that were resistant (52\%) or intermediate $(48 \%)$ in sensitivity to metalaxyl were identified within the field in Sampson County. There was a greater percentage of metalaxyl resistant $(82 \%)$ than intermediate isolates $(22 \%)$ in the field in Washington County (Fig. 3A). No metalaxyl sensitive isolates were identified among the US-8 isolates from any of these

TABLE 3. Description of genotypes of Phytophthora infestans identified in North Carolina between 1993 and 1998

\begin{tabular}{|c|c|c|c|c|c|c|}
\hline Genotype $^{a}$ & Gpi & Pep & Mating type & $\begin{array}{c}\text { Mitochondrial } \\
\text { haplotype }\end{array}$ & $\begin{array}{c}\text { Metalaxyl } \\
\text { sensitivity }^{\mathrm{b}}\end{array}$ & RG57 fingerprint ${ }^{c}$ \\
\hline US-1 & $86 / 100$ & $92 / 100$ & A1 & $\mathrm{Ib}$ & $\mathrm{S}$ & 1010101011001101000110011 \\
\hline US-6 $6^{\mathrm{d}}$ & $100 / 100$ & $92 / 100$ & A1 & IIb & $\mathrm{R}$ & 1010111001001100010110011 \\
\hline US-7 & $100 / 111$ & $100 / 100$ & A 2 & $\mathrm{Ia}$ & $\mathrm{S}$ to $\mathrm{R}$ & 1000100001001101010110011 \\
\hline US-8 & $100 / 111 / 122$ & $100 / 100$ & A 2 & Ia & I to $\mathrm{R}$ & 1000100001001101000110111 \\
\hline US-15 & $100 / 100$ & $92 / 100$ & A2 & $1 \mathrm{a}$ & nde $^{\mathrm{e}}$ & 1000100001001110010110011 \\
\hline US-18 & $100 / 100$ & $92 / 100$ & A2 & $\mathrm{Ia}$ & S to I & 1000100001001101000110011 \\
\hline US-19 & $100 / 100$ & $92 / 100$ & A2 & Ia & $\mathrm{S}$ to $\mathrm{I}$ & 1010101000001101000110011 \\
\hline
\end{tabular}

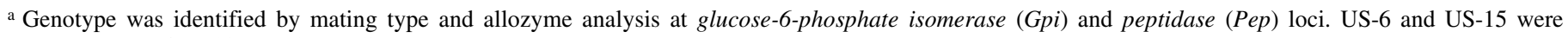
genotypes not found in North Carolina.

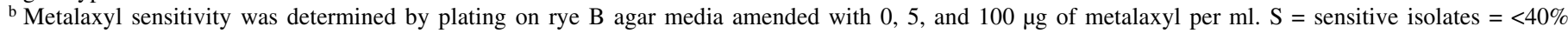
growth at $5 \mu \mathrm{g}$ of metalaxyl per $\mathrm{ml}$. I = intermediate isolates $=>40 \%$ growth at $5 \mu \mathrm{g} / \mathrm{ml}$ and $<40 \%$ growth at $100 \mu \mathrm{g}$ of metalaxyl per ml. $\mathrm{R}=$ resistant isolates $=>40 \%$ growth at $100 \mu \mathrm{g}$ of metalaxyl per $\mathrm{ml}$.

${ }^{c}$ Presence (1) or absence (0) of RG57 fingerprint bands. Bands 1 to 25 are indicated from left to right.

$\mathrm{d}$ Genotypes not observed in North Carolina but used for analysis.

e Not determined. 
three potato fields (Fig. 3A). Metalaxyl sensitivity was similar among isolates from tubers, leaves, and stems of potato sampled in the field in Washington County in 1997. Seventy-five percent of isolates obtained from tubers were metalaxyl resistant, and $25 \%$ of isolates were intermediate in sensitivity to metalaxyl. Similarly, $70 \%$ of isolates from leaves or stems of plants were resistant to metalaxyl (Fig. 3B).

\section{DISCUSSION}

Genetic changes have occurred in the structure of late blight population on tomatoes in western $\mathrm{NC}$ over time. Late blight epidemics on tomato in NC in 1993 and 1994 were caused primarily by the US-7 genotype (11). The US-7 genotype was also the predominant genotype detected during 1993 throughout the United States on tomato and potato $(21,22)$. US-7 isolates are tomato-aggressive (31). In contrast, after 1995, isolates of the US7 genotype were not recovered from tomato fields sampled at Waynesville and Fletcher, NC, and it has been uncommon elsewhere in the United States (19). The US-18 and US-19 genotypes have been the only genotypes recovered each year since 1995 in tomato sampled in western NC and these genotypes have not been reported elsewhere in the United States (19). The US-17 genotype reported elsewhere on tomato has not been found in NC (19).

The origin of the US-18 and US-19 genotypes is still under investigation. The US-18 and US-19 genotypes have an allozyme genotype (Gpi 100/100 and Pep 92/100) and a mating type similar to the US-15 genotype found on tomato in Pennsylvania during

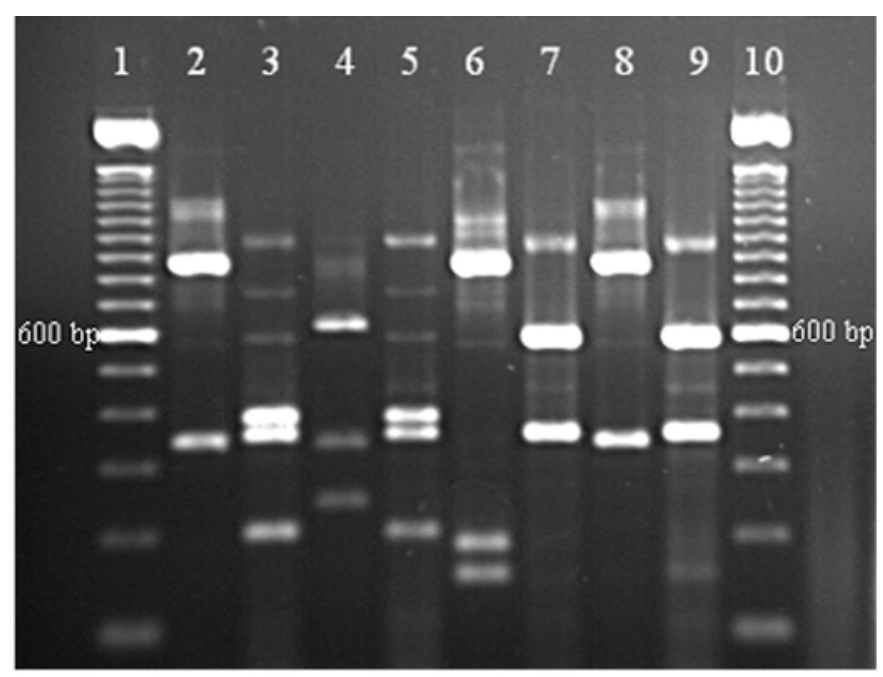

Fig. 2. Mitochondrial DNA haplotypes of Phytophthora infestans. DNA from every other lane was amplified with the $\mathrm{P} 2$ and $\mathrm{P} 4$ primer pairs. $\mathrm{P} 2$ products were digested with $M s p \mathrm{I}$ and $\mathrm{P} 4$ products were digested with EcoRI. Type Ia, Ib, IIa, and IIb haplotypes are shown in lanes 2 to 3, 4 to 5, 6 to 7, and 8 to 9, respectively. Lanes 1 and 10, 100-bp DNA ladder.
1994 (19). However, the DNA fingerprint pattern of the US-15 genotype is clearly different from both US-18 and US-19. In our study, the DNA fingerprint pattern of the US-18 genotype was very similar to the US- 8 genotype, except band 23 did not appear in the US-18 genotype. The US-18 genotype most likely resulted from recombination between the US- 1 and US- 8 genotype because both genotypes have occurred in NC previously on tomato.
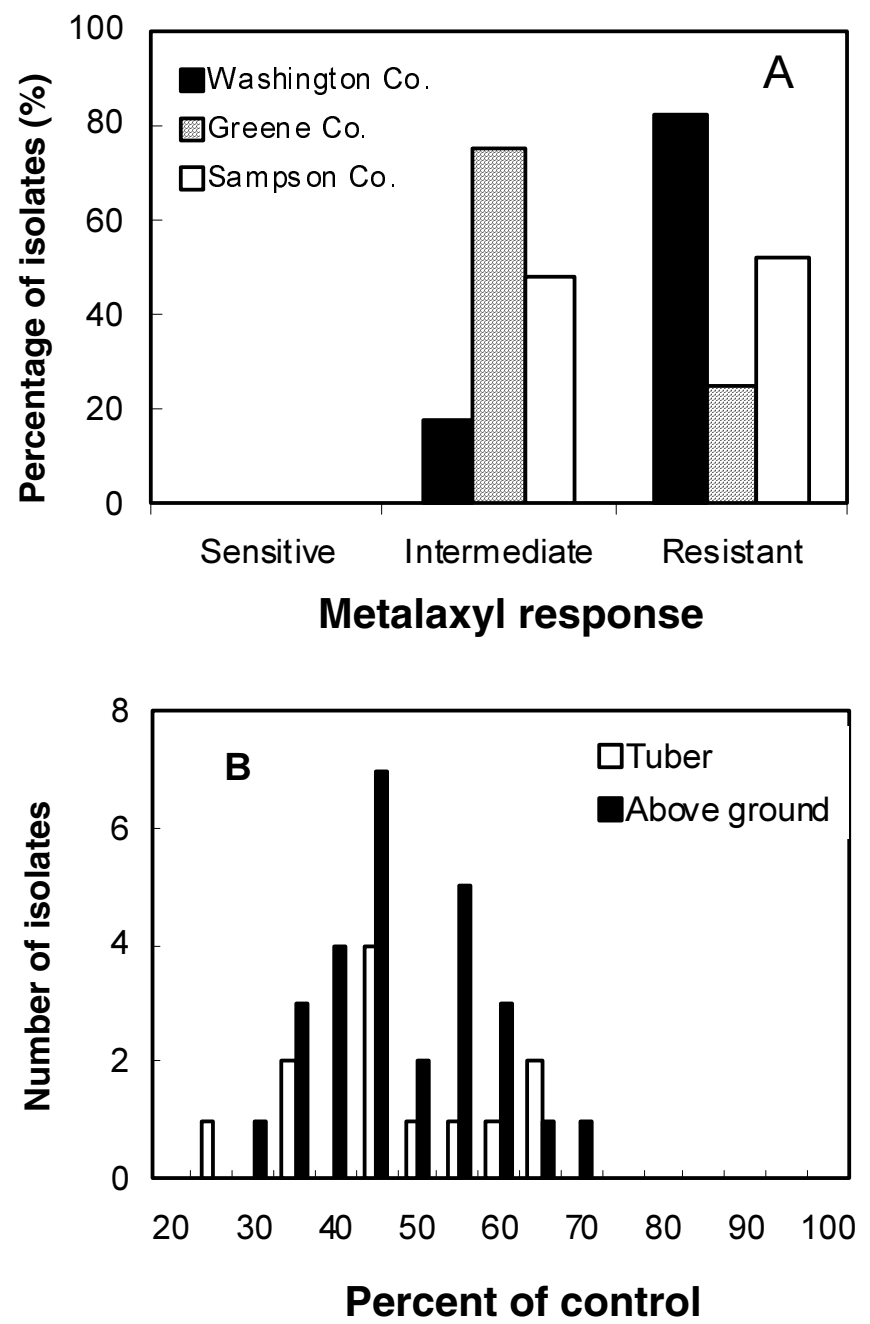

Fig. 3. Variation in metalaxyl sensitivity among isolates of Phytophthora infestans. A, Percentage of isolates that were sensitive, intermediate, or resistant to metalaxyl within three different field locations in Washington, Greene, and Sampson counties. Total numbers from each field were 39, 16, and 29 isolates, respectively. B, Growth of isolates of $P$. infestans on rye B media amended with $100 \mu \mathrm{g}$ of metalaxyl per ml expressed as a percentage of the nonamended control. Growth of the 12 isolates from tubers is compared to growth of 27 isolates from above ground portions of plants within the field in Washington County.

TABLE 4. Metalaxyl sensitivity and genotype of isolates of Phytophthora infestans collected from potato and tomato in North Carolina between 1993 and 1998

\begin{tabular}{|c|c|c|c|c|c|c|c|c|}
\hline \multirow[b]{3}{*}{ Response to metalaxyl ${ }^{\mathrm{a}}$} & \multicolumn{8}{|c|}{ Number of isolates } \\
\hline & \multicolumn{4}{|c|}{ Tomatoes } & \multicolumn{3}{|c|}{ Potatoes } & \multirow[b]{2}{*}{ Total } \\
\hline & US-7 & US-8 & US-18 & US-19 & US-1 & US-7 & US-8 & \\
\hline Sensitive & 2 & 0 & 19 & 4 & 1 & 0 & 0 & 26 \\
\hline Intermediate & 6 & 3 & 1 & 1 & 0 & 1 & 45 & 57 \\
\hline Resistant & 44 & 11 & 0 & 0 & 0 & 1 & 74 & 130 \\
\hline
\end{tabular}

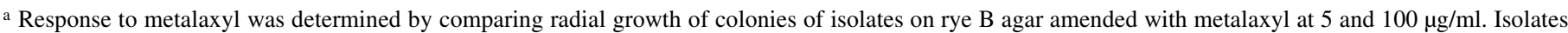
growing less than $40 \%$ of nonamended control plate at 5 and $100 \mu \mathrm{g}$ of metalaxyl per ml were sensitive. Isolates growing greater than $40 \%$ of nonamended control plate at $5 \mu \mathrm{g} / \mathrm{ml}$ but less than $40 \%$ of nonamended control plate at $100 \mu \mathrm{g} / \mathrm{ml}$ were metalaxyl intermediate. Isolates growing greater than $40 \%$ of nonamended control plate at both 5 and $100 \mu \mathrm{g} / \mathrm{ml}$ were metalaxyl resistant. 
The hypothesis that the US-18 developed as a result of a mating type switch from an isolate of the US-6 genotype (11) is not supported by our genetic data or by the fact that the US- 6 genotype has never been found in NC tomato fields. The US-6 genotype (Gpi 100/100 and Pep 92/100) was introduced into the United States in the late 1970s and was the most common and widespread genotype in the United States and Canada during 1987 and 1991 (14). The US-18 was first observed in fields in eastern Tennessee in 1994 (11), so there is a possibility that it migrated into NC from elsewhere.

The allozyme genotype of US-19 was identical to US-18, but DNA fingerprints were different. Unlike US-18, US-19 had additional bands 3 and 7 and lacked band 10 (Table 3; Fig. 1). DNA fingerprints of the US-19 genotype were most similar to the US-1 and US-6 genotypes with the exception that bands 9 and 10 from US- 1 and bands 6, 10, and 18 from US-6 were not present in the US-19 genotype. This genotype could have arisen via recombination or have resulted from somatic variation in the US-6. Further studies are needed to support either hypothesis.

Genetic changes in the structure of late blight populations on potato in NC occurred in the earlier 1990s when the US-1 clonal lineage was replaced by the US-8 genotype (11). Prior to 1984, US-1 was the predominant genotype in populations of $P$. infestans outside Mexico (12,13). The US-1 genotype was also reported in NC in 1994 by others (19). After the detection of A2 mating type outside Mexico in 1984, changes in populations of $P$. infestans occurred in Europe and subsequently worldwide $(1,6,9,14)$. Since 1994 , the US-8 genotype is the only genotype that has been found on potato in NC. The US-8 genotype has probably increased rapidly because it is more aggressive than the US-7 genotype on potato $(19,22,28,31)$. Late blight on potato caused by the US-8 genotype still occurs in NC and elsewhere in the United States (19). The US-11 genotype (A1 mating type) reported in 1996 and 1997 in western Washington $(7,15)$ has not yet been observed in potato fields in NC.

Our genetic data indicate that the source of inoculum of late blight epidemics on potato and tomato are distinct in NC. On potatoes, the US-8 genotype is most likely brought into potato growing regions in eastern $\mathrm{NC}$ by importation of infected seed tubers. Both the US-1 and US-8 genotypes have been found in the seed producing areas of the northeast and Canada where growers purchase seed $(24,32)$. Tuber blight was found in an eastern NC potato field for the first time in 1997 and infected seed tubers were observed. Infected potato tubers used as seed may play an important role as source of initial inoculum in epidemics of late blight in the field. Because tuber blight on mature tubers has not been commonly observed in potato fields in eastern $\mathrm{NC}$, new infections most probably result from the importation of infected seed each year and not from overwintering of infected daughter tubers in soil. Initial epidemics in the fields in Washington, Sampson, and Green counties also spread from distinct foci indicating potential seedborne inoculum.

The source of inoculum for late blight epidemics on tomato is clearly different than potato. Most tomato growers in NC produce their own tomato transplants that are generally free of disease. However, extensive tomato production in Florida during winter may provide a migration route for $P$. infestans up the East Coast (11). In addition, inoculum from unsprayed tomatoes planted in home gardens may initiate epidemics. Repeated recovery of the US-18 genotype suggests that it may be surviving from season to season on tomato debris in western NC. The possibility that isolates of the US-18 genotype may survive on weed hosts or on tomato fruit and plant debris left in fields needs further exploration (33). The cool weather and mild winters in tomato growing areas in western NC may support recovery of the pathogen after overwintering.

mtDNA haplotypes were identified for some of the isolates of $P$. infestans collected. All isolates were identified as the Ia haplotype
(US-7, US-8, US-18, and US-19 genotypes) with the exception of the US-1 genotype, which was the Ib haplotype. Recent isolates collected in western Europe were also predominately the Ia haplotype $(4,29)$. The IIa and IIb haplotypes were not found in NC on either tomato or potato but were identified from isolates obtained from other regions in the United States, Canada, and Ireland (2). mtDNA in $P$. infestans is believed to be inherited maternally from parents to progeny without recombination during sexual reproduction $(1,15)$. All the genotypes of $P$. infestans occurring in NC are from a common mtDNA lineage.

Our data indicate that variation in metalaxyl sensitivity occurred within the US-8 genotype from the potato fields sampled. Variation among isolates within genotypes collected from different geographic locations has been reported previously, but there are few reports of variation among isolates of the same genotype collected from the same field $(11,22)$. Research on metalaxyl sensitivity of isolates of $P$. infestans from Mexico (20) and Israel $(26,27)$ has shown that metalaxyl resistant isolates have a higher degree of fitness than metalaxyl sensitive isolates. Studies, including this one, have found that the level of resistance to metalaxyl is unrelated to the fungicide history of the field, suggesting migration of resistant isolates $(11,16,22)$. Resistance to metalaxyl in $P$. infestans is associated with a single dominant gene and variation among isolates of the same clonal genotype may involve minor genes $(10,30)$.

Isolates of the US-18 and US-19 genotypes collected from tomato fields remained sensitive to metalaxyl over a 4-year period. This suggests that fungicide sensitive isolates do not have reduced fitness compared with resistant isolates (27). However, further experimentation is needed to test this hypothesis. Metalaxyl is not used routinely on tomatoes in NC. Nevertheless, sensitivity to metalaxyl in these genotypes makes the use of the fungicide on tomatoes a possibility in some fields where known sensitive genotypes occur.

Knowledge of the genetic structure of populations of $P$. infestans within $\mathrm{NC}$ on tomato and potato will be useful for development of improved management strategies for the pathogen. Data from previous genotype surveys of pathogen populations on tomato may not be predictive of the genotypes in successive epidemics in subsequent years on tomato crops in the state. In contrast, genotypes on potatoes are genetically less heterogeneous and have predominately been US-8 since 1995 in NC. Information on genotypes that occur in potato seed production areas in Maine and Canada that ship potato seed tubers into $\mathrm{NC}$ will continue to be important for disease management in the future $(19,24,32)$. One recent study indicated that fungicide treatments of seed pieces reduce sporulation of $P$. infestans on tuber surfaces and increase plant emergence (25). Integrated management techniques, including the use of pathogen-free seed potatoes and tomato transplants, use of PCR for development of clean seed $(34,37)$, elimination of sources of inoculum, use of fungicides on both seed tubers and foliage, host resistance, and disease forecast modeling will help growers minimize losses caused by this devastating disease.

\section{ACKNOWLEDGMENTS}

We thank W. Fry, Cornell University, for sending the RG57 probe and isolates; S. Kim, Pennsylvania Department of Agriculture, for sending isolates for use in this research; G. Griffith and D. Shaw, University of Wales, Bangor, for sharing protocols and primers for mtDNA haplotyping; former graduate assistant D. Fraser for use of her isolates and data from previous work with the pathogen; and graduate assistant L. Gomez for assistance with the RFLP analysis.

\section{LITERATURE CITED}

1. Carter, D. A., Archer, S. A., Buck, K. W., Shaw, D. S., and Shattock, R. C. 1991. DNA polymorphism in Phytophthora infestans: The UK experience. Pages 273-294 in: Phytophthora. J. A. Lucas, R. C. Shattock, 
D. S. Shaw, and L. R. Cooke, eds. Brit. Mycol. Soc., Cambridge University Press, Cambridge.

2. Chycoski, C. I., and Punja, Z. K. 1996. Characteristics of populations of Phytophthora infestans from potato in British Columbia and other regions of Canada during 1993 to 1995. Plant Dis. 80:579-589.

3. Davidse, L. C., Looyen, D., Turkensteen, L. J., and Van der Wal, D. 1981. Occurrence of metalaxyl resistant strains of Phytophthora infestans in Dutch potato fields. Neth. J. Plant Pathol. 87:65-68.

4. Day, J. P., and Shattock, R. C. 1997. Aggressiveness and other factors relating to displacement of populations of Phytophthora infestans in England and Wales. Eur. J. Plant Pathol. 103:379-391.

5. Deahl, K. L., DeMuth, S. P., Linden, S. L., and Rivera-Pena, A. 1995. Identification of mating types and metalaxyl resistance in North American populations of Phytophthora infestans. Am. Potato J. 72:35-49.

6. Deahl, K. L., Goth, R. W., Young, R., Sinden, S. L., and Gallegly, M. E. 1991. Occurrence of the A2 mating type of Phytophthora infestans in potato fields in the United States and Canada. Am. Potato J. 68:717-726.

7. Dorrance, A. E., Inglis, D. A., Derie, M. L., Brown, C. R., Goodwin, S. B., Fry, W. E., and Deahl, K. L. 1999. Characterization of Phytophthora infestans populations in western Washington. Plant Dis. 83:423-428.

8. Drenth, A., Tas, I. C. Q., and Govers, F. 1994. DNA fingerprinting uncovers a new sexually reproducing population of Phytophthora infestans in the Netherlands. Eur. J. Plant Pathol. 100:97-107.

9. Drenth, A., Turkensteen, L. J., and Govers, F. 1993. The occurrence of the A2 mating type of Phytophthora infestans in The Netherlands: Significance and consequences. Neth. J. Plant Pathol. 99:57-67.

10. Fabritius, A. L., Shattock, R. C., and Judelson, H. S. 1997. Genetic analysis of metalaxyl insensitivity loci in Phytophthora infestans using linked DNA markers. Phytopathology 87:1034-1040.

11. Fraser, D. E., Shoemaker, P. B., and Ristaino, J. B. 1999. Characterization of isolates of Phytophthora infestans from tomato and potato in North Carolina from 1993 to 1995. Plant Dis. 83:633-638.

12. Fry, W. E., and Goodwin, S. B. 1997. Resurgence of the Irish potato famine fungus. BioScience 47:363-371.

13. Fry, W. E., Goodwin, S. B., Dyer, A. T., Matuszak, J. M., Drenth, A., Tooley, P. W., Sujkowski, L. S., Koh, Y. J., Cohen, B. A., Spielman, L. J., Deahl, K. L., Inglis, D. A., and Sandlen, K. P. 1993. Historical and recent migrations of Phytophthora infestans: Chronology, pathways, and implications. Plant Dis. 77:653-661.

14. Fry, W. E., Goodwin, S. B., Dyer, A. T., Matuszak, J. M., Spielman, L. J., and Milgroom, M. G. 1992. Population genetics and intercontinental migrations of Phytophthora infestans. Annu. Rev. Phytopathol. 30:107129.

15. Gavino, P. D., Smart, C. D., Sandrock, R. W., Miller, J. S., Hamm, P. B., Lee, T. Y., Davis, R. M., and Fry, W. E. 2000. Implications of sexual reproduction for Phytophthora infestans in the United States: Generation of an aggressive lineage. Plant Dis. 84:731-735.

16. Goodwin, S. B., Cohen, B. A., Deahl, K. L., and Fry, W. E. 1994. Migration from northern Mexico as the probable cause of recent genetic changes in populations of Phytophthora infestans in the United States and Canada. Phytopathology 84:553-558.

17. Goodwin, S. B., Drenth, A., and Fry, W. E. 1992. Cloning and genetic analyses of two highly polymorphic, moderately repetitive nuclear DNA's from Phytophthora infestans. Curr. Genet. 22:107-115.

18. Goodwin, S. B., Schneider, R. E., and Fry, W. E. 1995. Use of celluloseacetate electrophoresis for rapid identification of allozyme genotypes of Phytophthora infestans. Plant Dis. 79:1181-1185.

19. Goodwin, S. B., Smart, C. D., Sandrock, R. W., Deahl, K. L., Punja, Z. K., and Fry, W. E. 1998. Genetic change within populations of Phytophthora infestans in the United States and Canada during 1994 to 1996: Role of migration and recombination. Phytopathology 88:939-949.
20. Goodwin, S. B., Spielman, L. J., Matuszak, J. M., Bergeron, S. N., and Fry, W. E. 1992. Clonal diversity and genetic differentiation of Phytophthora infestans populations in northern and central Mexico. Phytopathology 82:955-961.

21. Goodwin, S. B., Sujkowski, L. S., Dyer, A. T., Fry, B. A., and Fry, W. E. 1995. Direct detection of gene flow and probable sexual reproduction of Phytophthora infestans in northern North America. Phytopathology 85: 473-479.

22. Goodwin, S. B., Sujkowski, L. S., and Fry, W. E. 1996. Widespread distribution and probable origin of resistance to metalaxyl in clonal genotypes of Phytophthora infestans in the United States and Canada. Phytopathology 86:793-800.

23. Griffith, G. W., and Shaw, D. S. 1998. Polymorphisms in Phytophthora infestans: Four mitochondrial haplotypes are detected after PCR amplification of DNA from pure cultures or from host lesions. Appl. Environ. Microbiol. 64:4007-4014.

24. Groves, C. T., and Champaco, E. R. 2001. Characterization of Phytophthora infestans collected in Maine, 1999-2000. (Abstr.) Phytopathology 91(suppl.):S33.

25. Inglis, D. A., Powelson, M. L., and Dorrance, A. E. 1999. Effect of registered potato seed piece fungicides on tuber-borne Phytophthora infestans. Plant Dis. 83:229-234.

26. Kadish, D., and Cohen, Y. 1992. Overwintering of metalaxyl-sensitive and metalaxyl- resistant isolates of Phytophthora infestans in potato tubers. Phytopathology 82:887-889.

27. Kadish, D., Grinberger, M., and Cohen, Y. 1990. Fitness of metalaxylsensitive and metalaxyl-resistant isolates of Phytophthora infestans on susceptible and resistant potato cultivars. Phytopathology 80:200-205.

28. Kato, M., Mizubuti, E. S., Goodwin, S. B., and Fry, W. E. 1997. Sensitivity to protectant fungicides and pathogenic fitness of clonal lineages of Phytophthora infestans in the United States. Phytopathology 87:973978.

29. Lebreton, L., and Andrivon, A. 1998. French isolates of Phytophthora infestans from potato and tomato differ in phenotype and genotype. Eur. J. Plant Pathol. 104:583-594.

30. Lee, T. Y., Mizubuti, E., and Fry, W. E. 1999. Genetics of metalaxyl resistance in Phytophthora infestans. Fungal Genet. Biol. 26:118-130.

31. Legard, D. E., Lee, T. Y., and Fry, W. E. 1995. Pathogenic specialization in Phytophthora infestans: Aggressiveness on tomato. Phytopathology 85:1356-1361.

32. Peters, R. D., Forster, H., Platt, H. W., Hall, R., and Coffey, M. 2001. Novel genotypes of $P$. infestans in Canada during 1994 to 1995. Am. J. Potato Res. 78:39-45.

33. Rubin, E., Baider, A., and Cohen, Y. 2001. Phytophthora infestans produces oospores in fruits and seeds of tomato. Phytopathology 91: 1074-1080.

34. Trout, C. L., Ristaino, J. B., Madritch, M., and Wangsomboondee, T. 1997. Rapid detection of Phytophthora infestans in late blight-infected potato and tomato using PCR. Plant Dis. 81:1042-1048.

35. Vega-Sanchez, M. E., Erselius, L. J., Rodriquez, A. M., Bastidas, O., Hohl, H. R., Ojiambo, P. S., Mukalazi, J., Vermeulen, T., Fry, W. E., and Forbes, G. A. 2000. Host adaptation to potato and tomato within the US1 clonal lineage of Phytophthora infestans in Uganda and Kenya. Plant Pathol. 49:531-539.

36. Wangsomboondee, T., Groves, C. T., Shoemaker, P. B., Cubeta, M. A., and Ristaino, J. B. 2000. Genetic diversity among isolates of Phytophthora infestans from tomato and potato in North Carolina. (Abstr.) Phytopathology 90(suppl.):S82.

37. Wangsomboondee, T., and Ristaino, J. B. 2002. Optimization of sample size and DNA extraction methods to improve PCR detection of different propagules of Phytophthora infestans. Plant Dis. 86:247-253. 